\title{
Prospects for individual economies
}

\section{United States}

After another relatively soft performance in the first quarter of the year, economic activity appears to have picked up significantly in the second quarter of 2018, underpinned by stronger consumption. The labour market has continued to strengthen with total nonfarm payroll employment expanding by 213,000 in June, almost identical to the 6-month average. The unemployment rate has increased marginally to 4 per cent due to a rise in the labour force participation rate (see figure 6). Labour markets are expected to continue to tighten, and the participation rate to increase somewhat as the economy expands. Fiscal policy is set to become expansionary over the course of this year and the next, with a projected reduction in tax revenue coupled with an increase in government spending leading to a widening of the government budget deficit and hence an increase in the debt position. As the fiscal stimulus takes more effect, we expect economic growth to strengthen through this year to about 3 per cent, marginally stronger than our forecast three months ago. The assessment of risks around the baseline forecast in the US economy is shown in the GDP growth rate fan chart (figure 7).

Figure 6. US: Unemployment and labour force participation rates

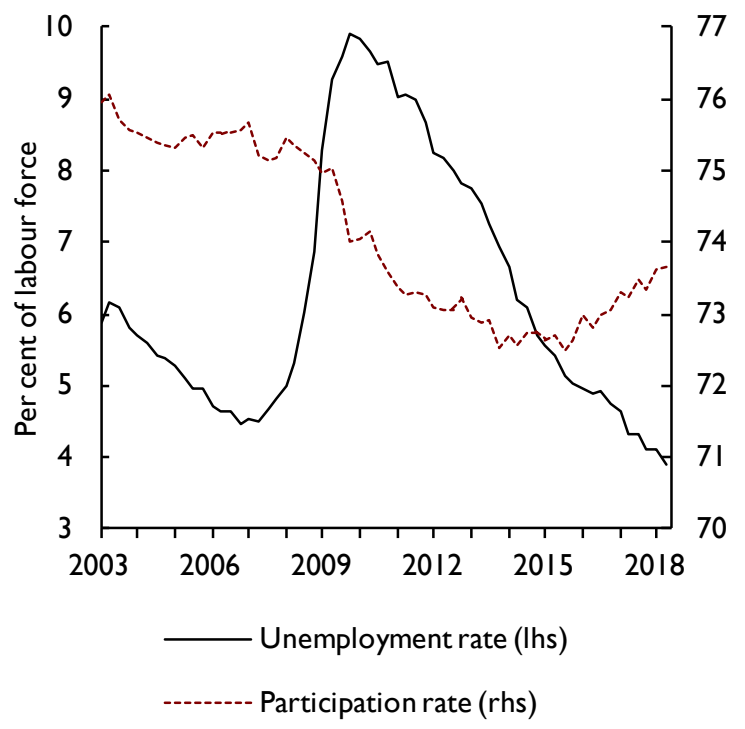

Source: NiGEM database and NIESR forecast.
After remaining below the Federal Reserve's target for the most of the time since 2012, inflation based on the consumer expenditure deflator is back to 2 per cent. Business surveys and the producer price index are indicating rising input costs that can be a result of tightening supply chains. However, the main driver of the rise in consumer price inflation so far has been health care costs, which are not trade related. The fiscal boost, coupled with the introduction of tariffs on imported goods, is expected to generate upward pressure on prices and, as a result, we expect inflation to overshoot the target slightly during the course of the next two years.

With the economy growing steadily, the Federal Reserve has continued its gradual monetary policy normalisation and increased the federal funds rate by 50 basis points in two rounds since the beginning of this year. With the economy operating already at about its capacity and a sizeable fiscal easing taking place, further increases in interest rates are expected.

Figure 7. US: Annual GDP growth fan chart (per cent per annum)

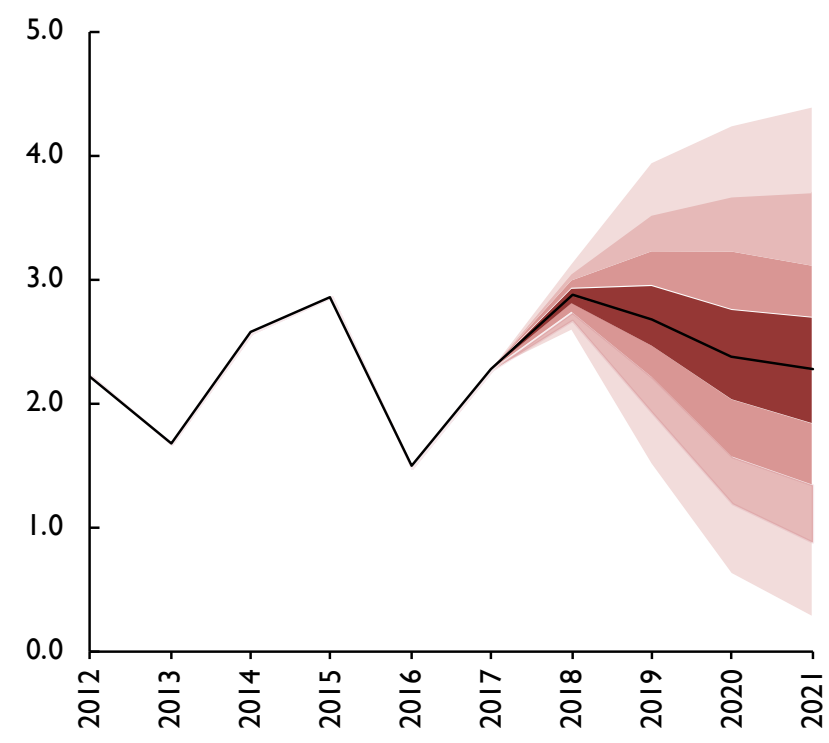

Source: NiGEM database, NIESR forecast and NiGEM stochastic simulations. 2018 outlook and fan are based partly on actual data.

Notes: The fan chart is intended to represent the uncertainty around the central forecast shown by the central line. There is a 10 per cent chance that GDP growth in any particular year will lie in any given shaded segment in the chart. There is a 20 per cent chance that GDP growth will lie outside the shaded area of the fan. 
Recent escalation of trade related disputes creates uncertainty and adds downside risks to the economic outlook. So far, the US tariffs have been aimed at intermediate products and the impact on output is expected to be modest. Based on our simulation (see Box A in this chapter) 25 per cent tariffs on $\$ 50$ billion worth of imports between the US and China is expected to reduce GDP (relative to the baseline case) in the US by about 0.05 per cent and increase inflation by about 0.1 percentage point in the first year. However, if the threat to impose more substantial tariffs on a much wider range of imported goods materialises, then the negative impact on the economy and the pass through to domestic inflation are expected to be much larger.

\section{Canada}

Despite finding itself in the direct firing line of US trade policy, the Canadian economy has so far remained resilient and has expanded at a pace very close to potential. However, the shift in the composition of GDP growth away from domestic consumption to exports and investment in the current trade environment may make it more vulnerable in the near term. GDP rose by only 0.3 per cent in the first quarter of 2018 , mainly due to a slowdown in household spending, nonenergy exports and housing investment, continuing the slower pace seen in the second half of 2017. Tighter mortgage rules and a slower pick-up of wage growth than under similar circumstances in the past look to be restraining consumption growth. On the other hand, the business outlook remains positive. As an energy producer, higher oil prices support export growth and business investment continues to profit from favourable financial conditions. Overall, we expect Canadian GDP to grow by 2.4 per cent in 2018, softening to around 2.2 per cent in 2019.

The stronger reliance on export-led growth makes the economic outlook more uncertain in the face of NAFTA renegotiations and the imposition of tariffs by the US administration and the counter-measures announced by the Canadian government. At the time this Review went to press, US tariffs in place on Canadian exports of newsprint, softwood lumber, steel and aluminium products affected 4.1 per cent of total Canadian exports. An escalation to include, for instance, the automobile sector would have substantially larger consequences for exporters and firms linked through supply chains as well as for business investment; while tariffs imposed by the Canadian government on US imports would put pressure on consumer prices (see also Box A).
Figure 8. Canada: Labour market developments

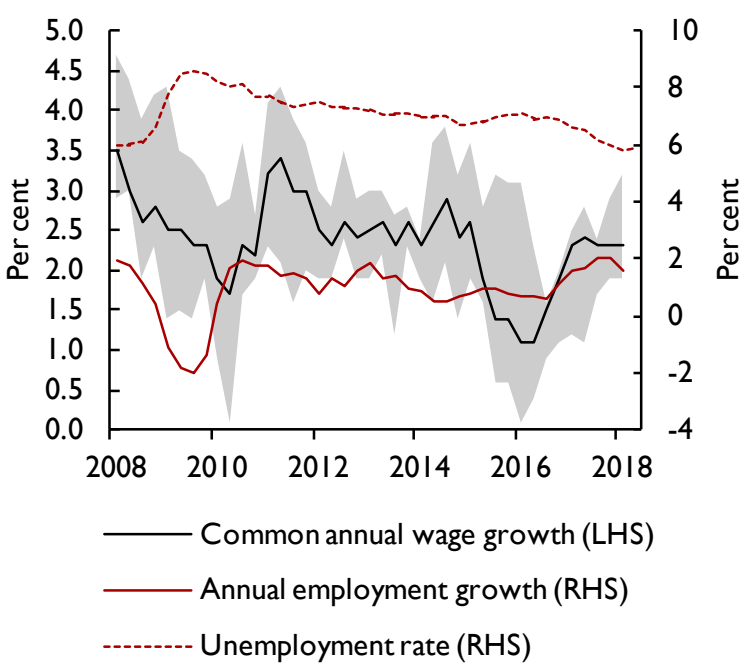

Source: Bank of Canada, NiGEM database and NIESR forecast. Note: The shaded area shows the difference between the maximum and minimum wage growth observation across sources by quarter.

Headline consumer price inflation in June stood near the middle of the Bank of Canada's target range at 2.5 per cent per annum, and so did the Bank's preferred measures of core inflation at close to 2.0 per cent (these include a trimmed inflation measure similar to the one examined for the UK in Box D of the UK Economy chapter). Abstracting from possible inflationary pressures arising from trade barriers, the inflation outlook is mixed. On one hand, indicators suggest that capacity constraints are increasingly binding - in the most recent Business Outlook Survey 57 per cent of firms reported facing difficulties meeting unanticipated increases in demand (up from 47 per cent in 2017) and 34 per cent of firms reported labour shortages (up from 25 per cent in 2017). On the other hand, signals about wage growth are mixed. Researchers at the Bank of Canada have constructed a measure that reflects a common wage growth component across a number of data sources (Brouillette et al., 2018). As illustrated in figure 8 , common wage growth has flatlined since the start of last year. At the same time, employment growth eased at the beginning of 2018 and unemployment rose slightly above its 40-year low to 6 per cent in June. Against this backdrop, the central bank continued its gradual path of raising interest rates by setting its main policy rate to 1.5 per cent in July, 25 basis points higher than after its last hike in January this year. We forecast inflation to hover around 2 per cent in 2018 and 2019 as a whole. 


\section{Euro Area}

In the Euro Area, growth in the first quarter of 2018 at 0.4 per cent was weaker than at any time in 2017 (at 0.7 per cent in each quarter). The lower reading raised the issue of whether the weakness was specific to that quarter (a temporary 'soft patch' due to factors such as the adverse weather) or a reflection of the above-par rate of growth in 2017 returning to trend. The 2.6 per cent growth in 2017 was the strongest since 2007.

Within the first quarter figures, Spain maintained its strong 0.7 per cent quarterly growth, while growth in France slipped from 0.7 per cent to 0.2 per cent and in Germany it dropped from 0.6 per cent to 0.3 per cent. Within the first quarter, Euro Area consumer spending growth actually strengthened, from 0.2 per cent to 0.5 per cent. In contrast, fixed investment spending growth dropped from a very strong 1.3 per cent in the first quarter of 2017 to 0.5 per cent. The external sector also contributed to the weaker performance, with strong quarterly export growth in the second half of 2017 (1.5 per cent in Q3 and 2.2 per cent in Q4) not being repeated in the first quarter of 2018 (see figure 9) when exports fell by 0.4 per cent and Germany, France and Italy all saw falls in exports. Our expectation is that this is likely to have been a temporary fall and that export growth will contribute to a strengthening of growth in the rest of the year. That said, overall growth is expected to slow from last year's very strong performance, to

Figure 9. Euro Area: Export growth

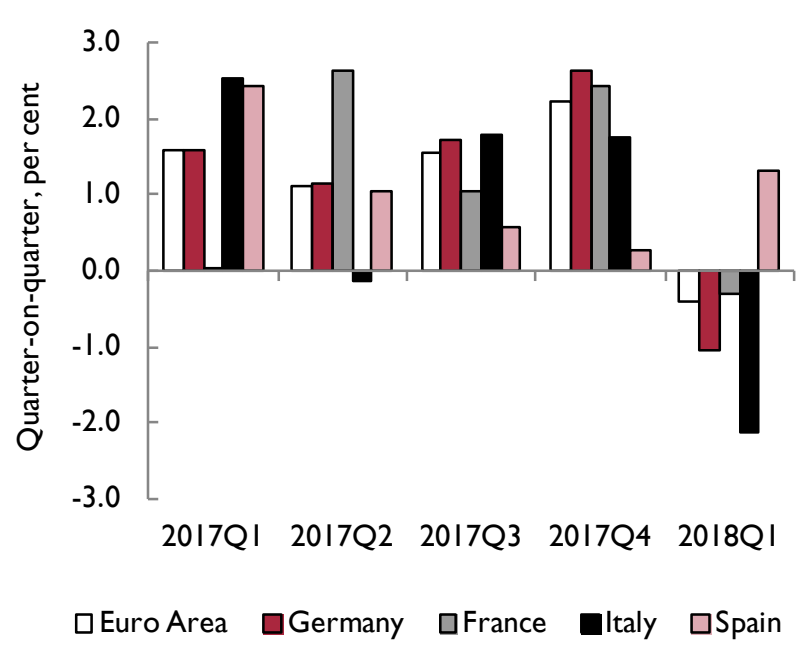

Source: NiGEM database.
2.2 per cent in 2018 , and 2.0 per cent next year. Into the medium term, the Euro Area is anticipated to show average annual growth of just under 1.5 per cent a year, reflecting broader demographic trends.

Consumer price inflation was 2.0 per cent in the twelve months to June, up sharply from 1.3 per cent in April, with the increase in the month widespread across the member countries. Increases in the prices of energy, services and food, alcohol and tobacco, were the main contributors to the sharp jump in annual inflation. Our expectation is that inflation will continue to remain "close to but below its 2 per cent" target over the forecast horizon.

If domestic price pressures, particularly from faster average earnings growth, build, then there could be a limited over-shoot of the 2 per cent target. Nevertheless, the European Central Bank (ECB) has indicated that it sees no immediate need to raise policy interest rates, perhaps implicitly viewing a sizeable output gap as preventing significant upward pressure on inflation, especially with the unemployment rate still currently above 8 per cent, and higher than its level before the financial crisis. Accordingly, while quantitative easing is expected to end this year (as announced by the ECB), the interest rate outlook is assumed to be for very gradual rate rises into the medium term.

Figure 10. Euro Area: GDP growth and inflation

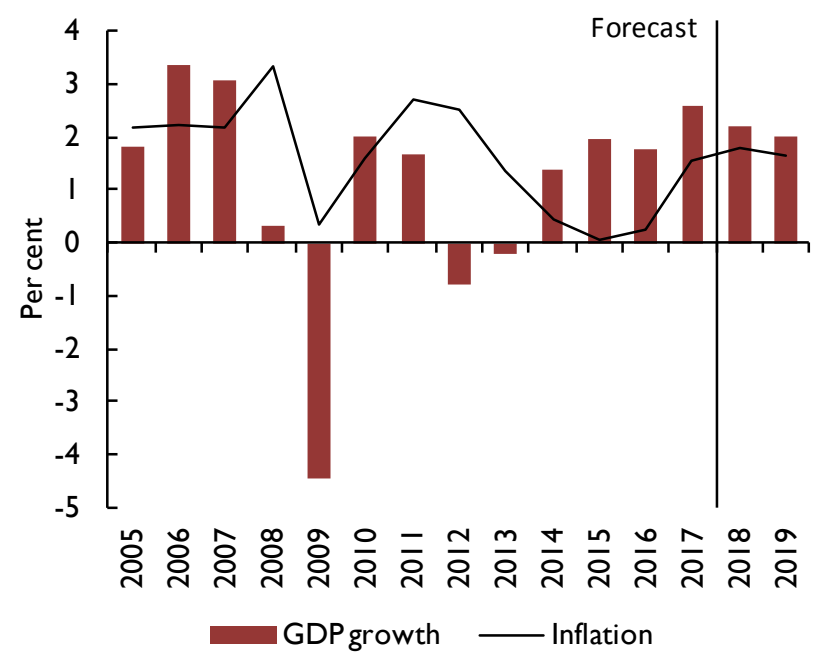

Source: NiGEM database and NIESR forecast. Note: Inflation is on HICP definition. 


\section{Germany}

Most recent indicators suggest that the German economy has left behind the soft patch it appeared to hit at the beginning of the year. We expect output growth to continue to be solid in 2018, albeit not as strong as in 2017. GDP expanded by only 0.3 per cent in the first quarter as a consequence of a global slowdown in trade and a severe influenza outbreak. Since then, orders data have picked up in May, as did industrial production.

As a result, we have revised our projections of GDP growth for 2018 to 2.1 per cent, and for 2019 to 2.0 per cent. Domestic demand is expected to make a substantial positive contribution to growth, as is demand from Euro Area trading partners. Fiscal policy will buffer the expected deceleration of growth, in particular in 2019 when most of the expansionary measures that were agreed by the German government in July will come into force. Given higher than expected revenue, the budgetary position remains favourable and would provide room for additional spending (see also Box B) should the government wish to use it. Additional spending could be used to upgrade the country's transport and broadband infrastructure in order to raise the economy's productive potential. We expect the government budget to remain in surplus over the whole of the forecast horizon.

The unemployment rate remains at a three-decade low of 3.4 per cent and shortages of labour are increasingly

Figure I I. Germany: GDP growth and inflation
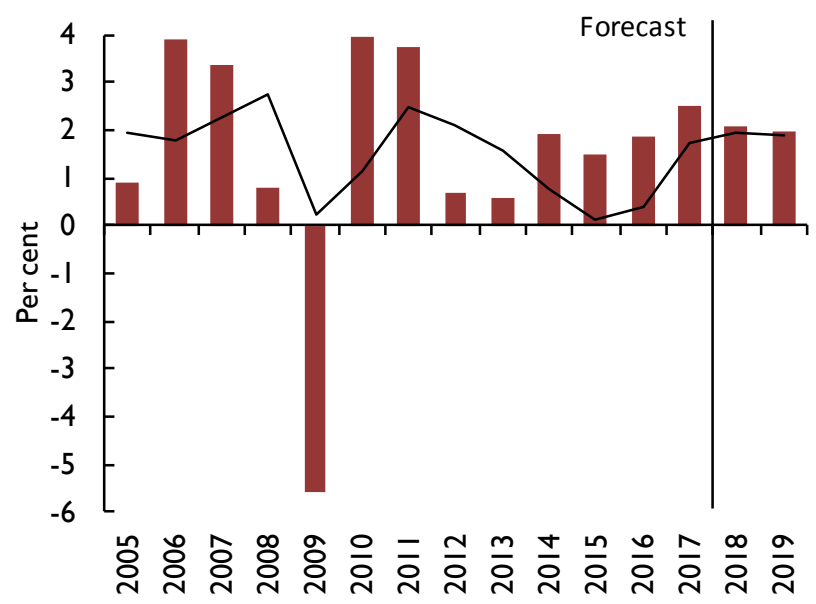

GDP growth Inflation

Source: NiGEM database and NIESR forecast.

Note: Inflation is on HICP definition. reported as constraining the rate of economic growth from moving above potential. Solid wage settlements in some sectors, like construction, the metal industries and the public sector, suggest that the reduction in slack may finally be translating into stronger wage pressure in areas that face particular recruitment difficulties. Low rates of overall unemployment, however, conceal the fact that the share of non-permanent employment contracts reached a 20 -year high of 8.3 per cent last year (IAB, 2018). This may explain why in the economy as a whole wages and inflation have struggled to move up further. Real wages were 1.1 per cent higher in 2018Q1 than a year previously, which is below the post-crisis average and more recent data on negotiated wages does not suggest this trend has yet reversed. Without a sustained rise in the pace of earnings increases, we expect consumer prices to rise by about 2.0 per cent in 2018 and 2019.

The main risk to the German economy is a slowdown in international trade as a result of new tariff and nontariff barriers (see also Box A). Figure 12 illustrates that the volume of exports to the United Kingdom has been falling since the Brexit referendum. Similarly, the growth in exports to the United States has slowed down over the past twelve months, despite favourable exchange-rate movements, possibly reflecting some fear about protectionist measures. German exporters have instead relied more on demand from the Euro Area and China. Political uncertainty in the currency union

Figure 12. Germany: Growth in exports to main trading partners

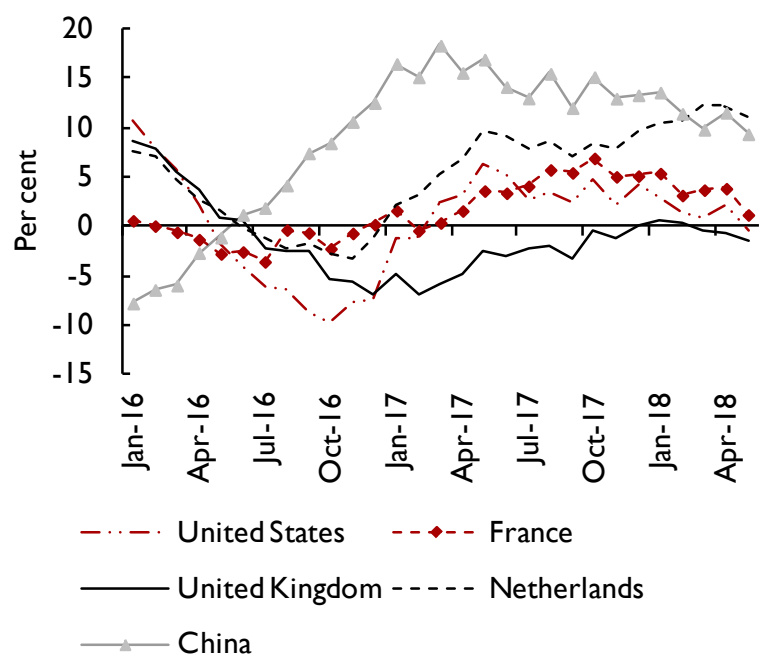

Source: Federal Statistical Office.

Note: Annual growth of export volumes in EUR, 6-month moving average. 
and an economic reversal in China would therefore have important implications for the German economy. Against this, the recent trade agreement between the EU and Japan should be positive for German exporters.

\section{France}

The French economy expanded in 2017 at a rate much faster than potential: 2.3 per cent versus a potential estimated at around $1 \frac{1 / 4}{4}$ per cent. ${ }^{3}$ In the first quarter of 2018, GDP growth slowed to 0.2 per cent after expanding by about 0.7 per cent in each of the previous four quarters, driven by a slowdown in consumption, investment and net trade. Household consumption growth was lacklustre at 0.1 per cent in the quarter as real personal income was hit by a combination of higher consumer price inflation, which rose from 1.2 per cent in the previous quarter to 1.5 per cent in the first quarter, and an increase in generalised social contribution (CSG), a tax on income and wealth used to finance social security. Fixed investment growth declined sharply from 0.9 per cent in the fourth quarter of 2017 to 0.2 per cent in the first quarter of 2018 . In addition to the slowdown in domestic demand, exports fell in the first quarter by 0.3 per cent as the euro appreciated against the US dollar, which made French exports less competitive. Although industrial production declined by 0.8 per cent in the three months to May 2018, service sector output rose by 0.5 per cent in the three months to April 2018 (after a rise of 1.7 per cent in the previous three months).

Figure 13. France: Harmonised consumer price inflation

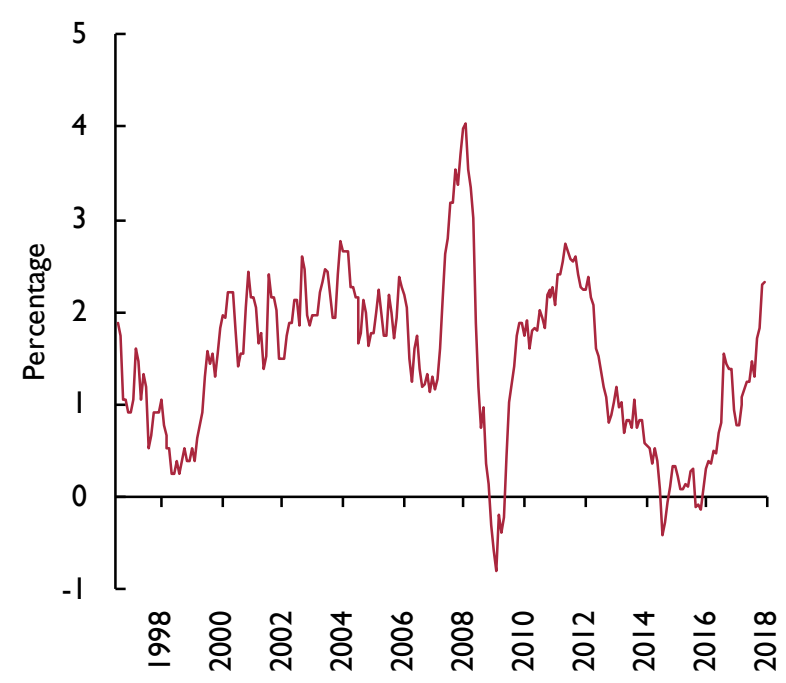

Source: NiGEM database and NIESR forecast.
Figure 14. France: GDP growth and inflation

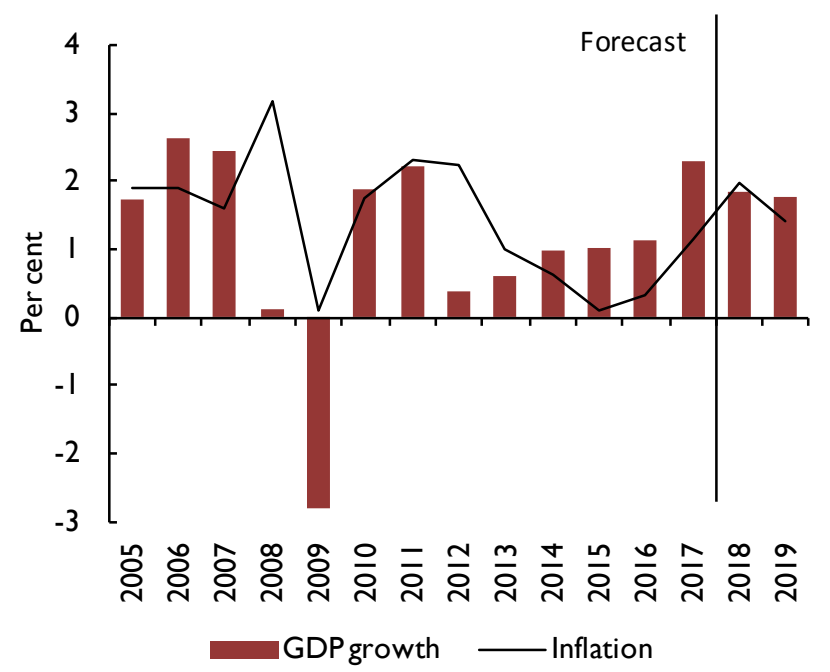

Source: NiGEM database and NIESR forecast.

Note: Inflation is on HICP definition.

The inflation rate reached 2.3 per cent in May and June, the highest since August 2012 (figure 13). Domestic factors - the economy growing above potential and closing its output gap - and external factors - a spike in energy prices - contributed to higher inflation. Higher inflation is likely to further dampen households' purchasing power unless earnings growth picks up.

The unemployment rate, which reached a peak of 10.5 per cent in 2015 , has been declining steadily but appears to have stalled at slightly above 9 per cent since the fourth quarter of 2017, as a result of slightly fewer new jobs being created and an increase in labour force participation. We expect the downward trend to resume in the second half of 2018 as there is still evidence of slack in the labour market. Following a temporary dip in the first quarter, we forecast quarterly French GDP growth to stabilise at around 0.4 per cent in each of the following three quarters and annual inflation to stabilise at just under 2 per cent.

\section{Italy}

Our annual projections for the short term are for continued economic expansion, although at a rate slightly weaker than we anticipated in May. We expect GDP to grow by 1.3 per cent this year and 1.2 per cent next. Since the turn of the year, growth has been slightly softer than expected, with the slowdown driven by the domestic political uncertainty and a deceleration in global trade. 
Consumption was the main driver of growth in the first quarter and we expect it to continue to be strong in the second quarter on the back of lower unemployment in the months to May and positive consumer confidence surveys. On the output side, the projections for the second quarter are for weak industrial production, partially compensated by stronger service sector output, in line with the outlook conveyed by activity surveys.

The headline inflation rate softened slightly during the first quarter of this year, but then rose to 1.4 per cent in June largely due to higher energy prices. We expect headline inflation to stabilise at just above 1 per cent this year and next. The unemployment rate could fall to just below 11 per cent in the second quarter of this year and we expect it to moderate below that in the rest of this year and the next.

The main risks to these projections are driven by the continued domestic political uncertainty and also the external trading environment. The process of coalition negotiations at the end of May added significant turbulence to financial markets and government bond yields which, although they have now stabilised somewhat, are still some 100 basis points above the levels in early May. Importantly, the new government has called into question the EU fiscal rules and that adds risk to our fiscal projections in the medium term (although we have not incorporated any new budget proposals to our forecasts as they will not be formally presented until autumn).

Figure 15. Italy: GDP growth and inflation

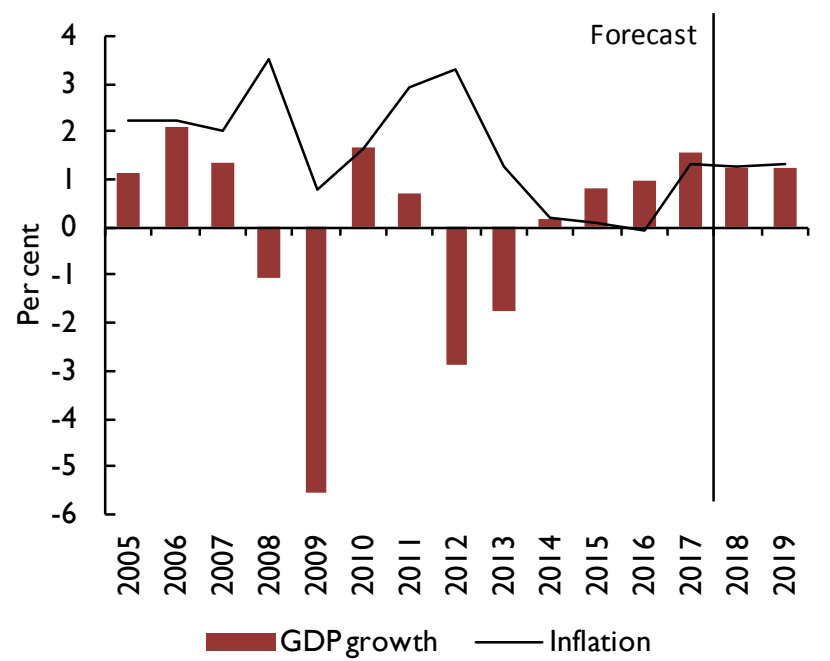

Source: NiGEM database and NIESR forecast.

Note: Inflation is on HICP definition.

\section{Spain}

The positive economic outlook in Spain continues to hold. Annual economic growth was 3 per cent in the first quarter of 2018, marking the twelfth consecutive quarter at which it has been 3 per cent or above. Unemployment has continued to fall steadily, from 16.1 per cent in March to 15.8 per cent in June. Prices increased by 2.3 per cent in the year to May, with inflation rising from 1.1 per cent in April, in part reflecting higher energy prices. Given the apparent degree of spare capacity remaining in the Spanish economy, the spike in inflation is likely to be due to the recent surge in oil prices.

There have been a number of important developments in the Spanish economy over the past quarter. Firstly, the government approved the 2018 Stability Programme in April. The main budgetary measures include income tax cuts for low income households and a 1 per cent increase in public sector wages. Secondly, the People's Party, which had held a majority since 2011, was replaced in government by the Spanish Socialist Workers' Party on 1 June following a vote on the corruption scandal. While this political crisis led to a sharp spike in economic policy uncertainty, the overall positive economic trends have continued.

Looking ahead, we forecast that economic growth will be around 2.8 per cent in 2018 and 2.5 per cent in 2019. Unemployment should continue to fall, reaching 15.5 per cent this year and around 14.5 per cent next. Inflation is likely to peak this year as

Figure 16. Spain: GDP growth and inflation

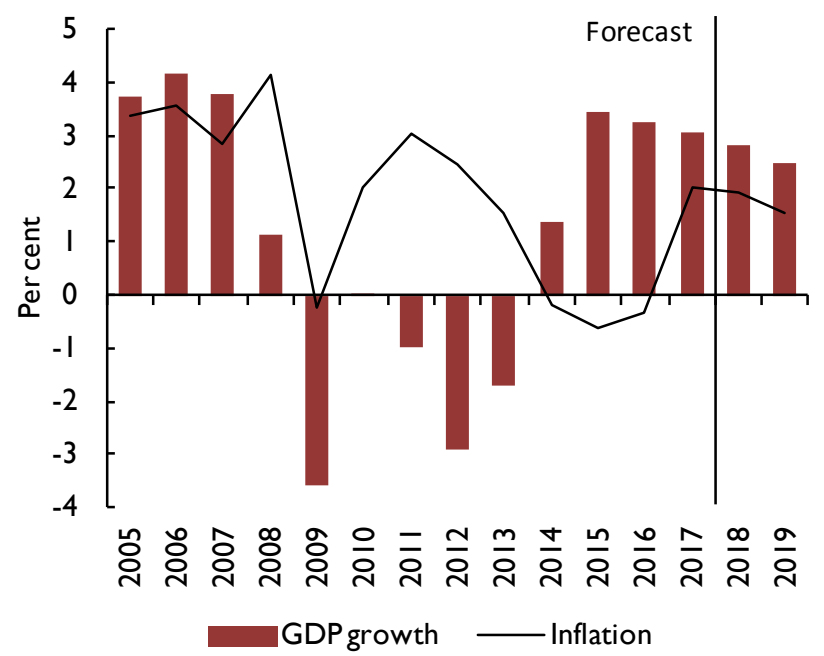

Source: NiGEM database and NIESR forecast.

Note: Inflation is on HICP definition. 
the energy price increase works through and edge back thereafter, reflecting the transitory effect of the increase in oil prices. With a robust outlook as our central forecast, the risks to our forecast are tilted to the downside. Domestically, the situation in Catalonia remains uncertain, while externally the key risks are a rise in protectionism and the effects of a gradual normalisation of monetary policies.

\section{Japan}

Japanese economic activity contracted by 0.2 per cent in the first quarter of 2018, down from an upwardly revised 0.3 per cent growth in the previous quarter. This is the first quarterly contraction since 2015 and was largely due to firms running down inventories, following a build-up of inventories in previous quarters. Housing investment also continued to decline following a contraction of bank lending for apartment construction as increasing numbers of new-builds lie vacant. Domestic demand was flat in the first quarter of this year. Since inventories are unlikely to continue to be run down and household consumption is likely to be supported in the near-term by rising wages, this fall in GDP looks to be temporary and we expect growth to return in the second quarter and for Japan to show growth of 1.0 per cent this year and next.

Consumer price inflation rose slightly to 0.7 per cent year-on-year in May, up from 0.6 per cent in April.

Figure 17. Japan: GDP growth and inflation

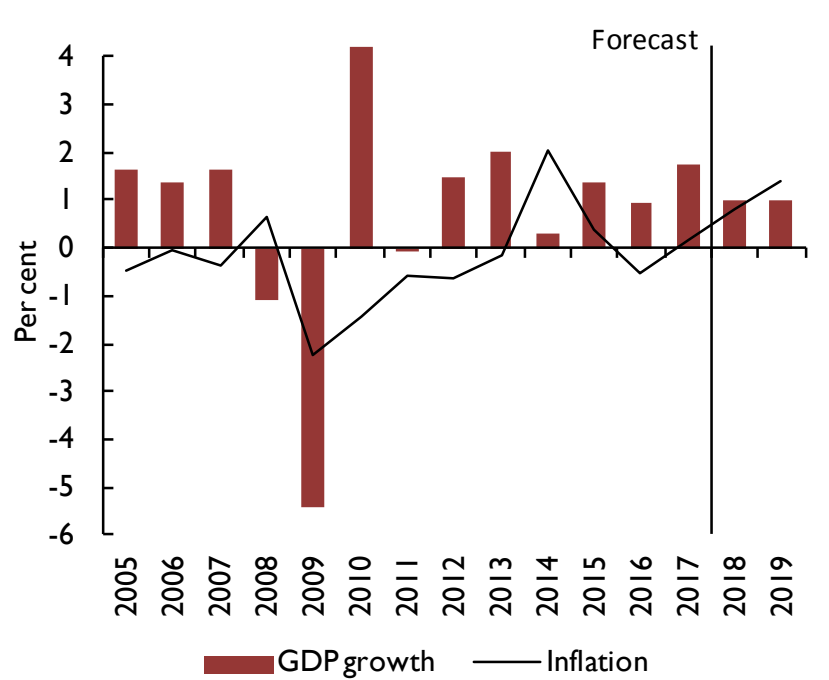

Source: NiGEM database and NIESR forecast.

Note: Inflation is consumer expenditure deflator.
While this reading was above consensus estimates of 0.3 per cent, it remains well below the rates of inflation seen in the first quarter of this year and the central bank's 2 per cent target. We expect inflation to edge up to 1.4 per cent in 2019, in part reflecting stronger wage growth, which for March showed the largest annual increase in earnings since 2003, with nominal earnings increasing by 2.1 per cent year-on-year. While this figure was boosted by large increases in bonus payments, base pay rose by 1.3 per cent, the strongest increase since 1997 . Although labour shortages are becoming increasingly acute, there has been little sign of pass-through to wages until now. To ease the problem of labour shortages, Japan is set to loosen immigration rules, allowing up to 500,000 guest workers into the country.

The Japanese government has pushed back its target date for achieving a primary budget balance to 2025, citing slow growth in tax revenues, a delay in raising the consumption tax and plans to increase spending on education as factors that meant the initial 2020 goal would be difficult to meet. From our forecast projections this target will prove to be tough to meet.

\section{China}

Output grew by 6.7 per cent year-on-year in the second quarter of 2018 , just 0.1 percentage point lower than in the preceding three quarters. Since the first quarter of this year, high frequency indicators have been pointing

Figure 18. China: Credit growth to non-financial corporations

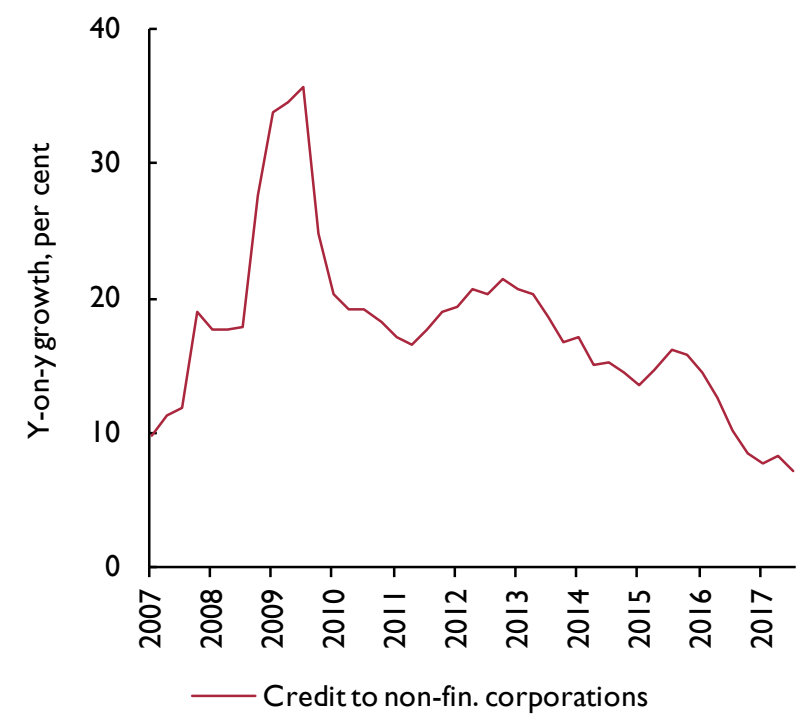

Source: Bank for International Settlements. 
to a somewhat softer pace of economic activity, largely as a reaction to financial deleveraging. The rate of growth of retail sales, investment and industrial output weakened in May and June. Looking forward, we maintain our view of a very gradual reduction in the rate of GDP growth and expect annual output growth to be about 6.6 per cent and 6.3 per cent this year and next respectively.

As the political drive to reduce financial risks continues, the pace of increase of corporate debt has slowed. After reaching a high of over 165 per cent of GDP in 2016, the ratio has edged down recently to around 160 per cent as policy changes have had an effect. Stricter financial rules seems to have affected liquidity as well, with the 12-month growth in M2 money supply for the past four months under 9 per cent and spreads between AA-rated corporate and government bond yields have risen since late 2016.

The introduction of a series of tariffs by the US on imports from China complicates implementation of domestic reforms. Tariffs imposed up to now are expected to have a modest impact on GDP growth and inflation. Based on our simulation results presented in Box A, the imposition of 25 per cent tariffs on $\$ 50$ billion worth of imports from China to the US and vice versa is expected to reduce (the level of) GDP in China by about 0.02 per cent and add about 0.2 percentage points to inflation in the first year.

Figure 19. China: Contributions to GDP growth

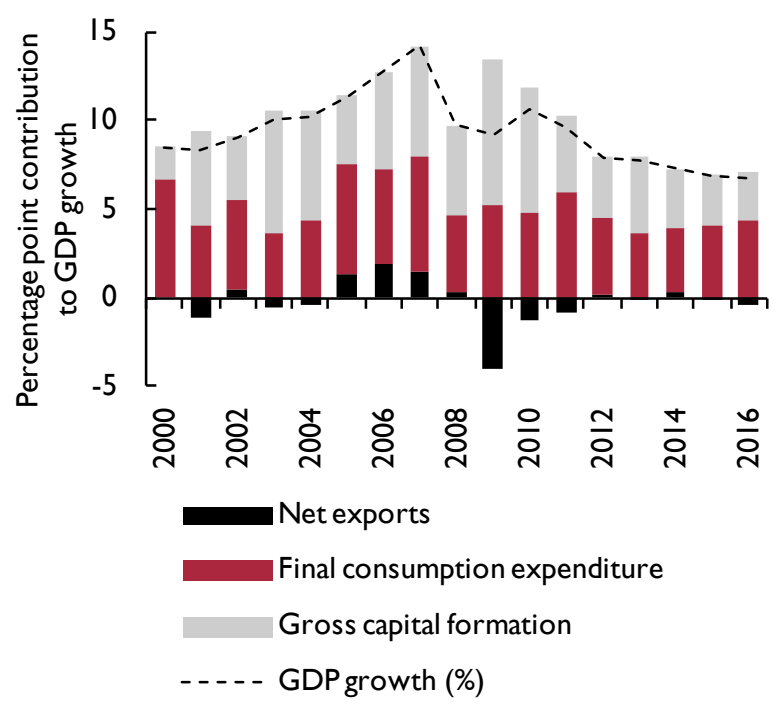

Source: National Bureau of Statistics of China.
However, the negative impact on the economy is expected to be significantly larger if a threat by the US President to apply tariffs on half or even the full range of imported goods from China materialises. News of the tariffs announcement led to a fall in Chinese domestic stock markets. Equity prices in China have declined by about 18 per cent since the start of this year, reaching lows last seen two years ago. The People's Bank of China reacted to the uncertainty by cutting banks' cash reserve ratio, which is a signal for banks to expand their balance sheets and hence liquidity in the system. However, as the statement accompanying the announcement stressed - the "prudent" monetary policy stance is expected to continue, which is an indication that the authorities are not planning a large stimulus. The escalation of the trade dispute creates uncertainty, increases volatility and creates a downside risk to economic activity. Nevertheless, output growth in China is largely domestically driven (see figure 19) and the government still has enough ammunition to soften the negative effect from the trade dispute with the US.

\section{Russia}

Following a landslide election victory on 18 March 2018 with 77 per cent of the vote, President Putin has set about his agenda. After the inauguration for another 6-year term on 7 May he signed a 'May decree' setting out the national development targets for the next term to 2024. The measures aim to raise Russia's potential growth rate, with the overriding objective of joining the group of the world's five largest economies by the end of the term (currently Russia is the world's 12th largest economy as measured at market exchange rates). The implementation of the 'May decree' requires an additional 8 trillion rubles (about US $\$ 130$ billion) over six years, which amounts to about half of total federal expenditure set out in Russia's 2018 budget. The plan is viewed as ambitious, with Prime Minister Medvedev admitting that the timeframe is "rather tight".

On 14 June 2018, the start of the World Cup held in Russia, the government outlined a package of budget measures to fund the 'May decree'. This contained three main components of note. First, value added tax (VAT) will rise from 18 per cent to 20 per cent from 2019. Second, the retirement age will increase from one of the lowest in the developed world - at 60 for men and 55 for women - to 65 and 60 for men and women respectively. Third, a tax reform of the oil industry will abolish export duties for crude and oil products and raise a production levy. International sanctions remain a key factor hindering recovery: in addition to the EU's further 
Figure 20. Russia: GDP growth and inflation

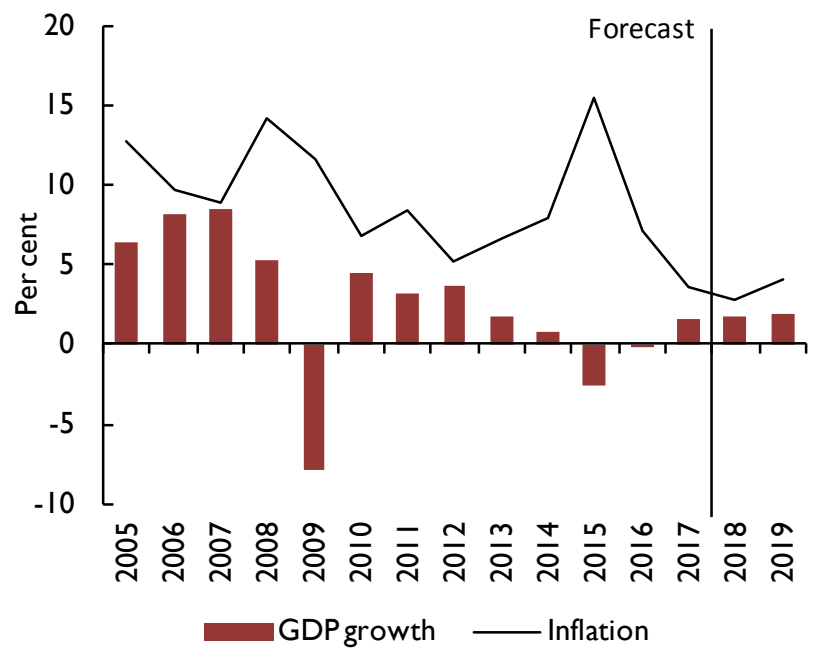

Source: NiGEM database and NIESR forecast. Note: Inflation is CPI.

extension of its economic sanctions until 31 January 2019 , there remains controversy over the alleged cyber interference in the 2016 US elections, and in June several companies and individuals had sanctions imposed for allegedly aiding Russia's main intelligence agency.

Annual consumer price inflation slowed a little to 2.3 per cent in June from 2.4 per cent in March. The decline in inflation into June was a result of seasonal lower food inflation. Having peaked at 16.9 per cent in the year to March 2015, inflation has now fallen below the Central Bank's target of 4 per cent, and has been around the 2.02.5 per cent range for the eight months to June 2018 . The VAT increase due to be implemented in January 2019 should lead to an uptick in inflation into 2019. The current harvest has been estimated to be some 2025 per cent lower than usual and will be another factor driving higher prices in the next 12-18 months. We expect inflation to pick up towards 2.7 per cent in 2018 and 4.0 per cent in 2019, reflecting the pass-through of exchange rate depreciation and commodity price rises to domestic prices. The VAT increase adds a further upside risk to inflation.

Following six rounds of reductions in interest rates which took them from 10 to 7.75 per cent in 2017, the central bank lowered its benchmark interest rate in midFebruary to 7.50 per cent and in late-March to 7.25 per cent, where it has been held since. At the 15 June 2018 meeting the Governor cited the forthcoming VAT increase as the main reason for postponing more monetary easing.
We have revised our GDP forecast down slightly to 1.8 per cent from 1.9 per cent in 2018 and to 1.9 per cent from 2.3 per cent in 2019 . The current year revision reflects the existing weakness in 2018 data, the weak harvest and tightening US sanctions, whilst the 2019 revisions reflect the balance of the new fiscal package.

\section{India}

The rate of growth of the Indian economy continued to increase in the first quarter of 2018, with the economy expanding by 7.7 per cent year-on-year, up from 7.0 per cent in the previous quarter. Some of this continued rapid expansion can be attributed to a continued bounce back following disruption due to demonetisation in November 2016 and the implementation of radical tax reforms in July 2017. However, a large contribution to growth has come from increases in government spending in the runup to next year's general election, while private investment has been broadly flat. India's economy had benefitted from the low oil price, but with oil at around $\$ 75$ per barrel, this stimulus to growth has been removed. Thus, unless private sector investment surprises on the upside, we expect growth to slow next year, averaging 7.8 per cent this year and 7.5 per cent in 2019.

The annual inflation rate increased for the third consecutive month in June, reaching 5.0 per cent. India's increasingly protectionist stance is likely to push up consumer prices further, as well as hurting domestic

Figure 2I. India: GDP growth and inflation

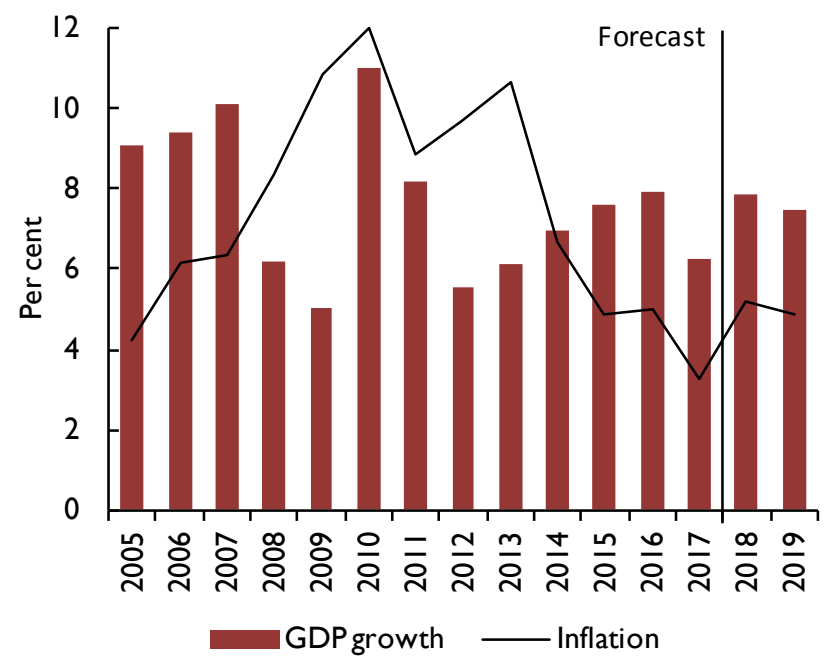

Source: NiGEM database and NIESR forecast. Note: Inflation is CPI. 
producers as the prices of imported goods rises. Increases in tariffs on a range of goods imported from the US will come into effect on 4 August, in retaliation for President Trump's decision to increase duties on steel and aluminium imports from India.

Increasing inflationary pressure and concerns around rising oil prices and uncertainty in financial markets prompted the Reserve Bank of India to raise policy interest rates on 6 June for the first time since 2014, with the benchmark repo rate rising by 25 basis points to 6.25 per cent. We expect inflation to average 5.2 per cent this year before easing slightly to 4.9 per cent in 2019 .

\section{Brazil}

Driven by stronger investment growth than anticipated, we have revised up our projections for GDP growth in Brazil for this year and next, with growth forecast at 2 per cent and 2.7 per cent respectively. The weakening of inflation from a peak of almost 9 per cent in 2015 to just above 3 per cent last year gave space for monetary policy to lower the policy rate to 6.5 per cent in March which is likely to support investment. Also, the recent reform plan from the government has improved confidence and restored stability in financial markets. Inflation is assumed to settle at a rate within the 2018 Central Bank's target of 3-6 per cent this year and the next, which will continue to provide space for an accommodative monetary policy stance, and further support investment and consumption. The regional, as well

Figure 22. Brazil: GDP growth and inflation

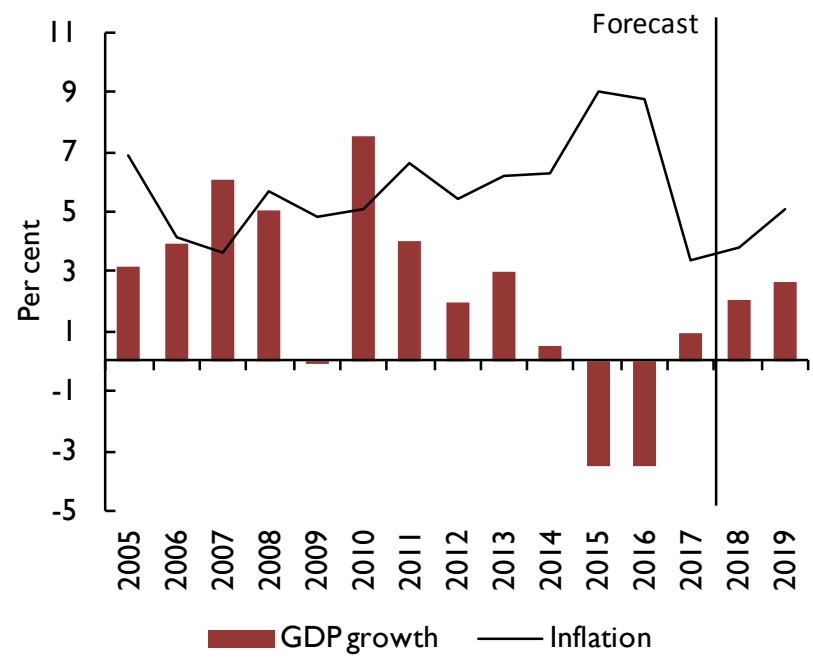

Source: NiGEM database and NIESR forecast.

Note: Inflation is CPI. as global, upturn in demand has driven a sustained increase in demand for Brazilian exports. This has aided the net trade position, although we expect the recent strength in exports to soften gradually going forward.

Some risks to these forecasts come from continued political uncertainty. The 2015-16 recession took its toll on traditional politics which had leaned to the left, and this may jeopardise the recent reform effort. According to the latest polls, the elections due in October 2018 could see an overhaul of the current left-wing government by a right-wing party. In addition, the adverse fiscal position represents a risk to our forecasts, as the primary balance required to stabilise the public debt ratio in the medium term is estimated to be around 2 per cent, while it currently stands at a negative 1.6 per cent of GDP.

\section{NOTES}

I 'Oil and the macroeconomy' (20I8), National Institute Economic Review, February.

2 The Vix index is seen as a barometer of investor sentiment and market volatility and is a measure of market expectations of uncertain volatility implied by S\&P 500 index option prices.

3 European Commission estimate: 1.3 per cent, French Treasury estimate: 1.25 per cent.

\section{REFERENCES}

Aksoy, Y., Basso, H.S. and Smith, R.P. (2017), 'Medium-run implications of changing demographic structures for the macroeconomy', National Institute Economic Review, August.

Brouillette, D., Lachaine, J. and Vincent, B. (2018), 'Wages: measurement and key drivers', Bank of Canada Staff Analytical Note 2018-2.

Hantzsche, A. and Liadze, I. (2018), 'The war on trade: beggar thy neighbour - beggar thyself?', National Institute Economic Review, May.

IAB (Institut für Arbeitsmarkt-und Berufsforschung) (20I8), IAB Kurzbericht, 16/2018.

Kazalova, Y. and Naisbitt, B. (2018), 'Disappointing productivity growth: an international dimension', National Institute Economic Review, February.

Lennard, J. (2018), 'The great synchronisation', National Institute Economic Review, May.

Lenoel, C. (20I8), 'Predicting recessions in the United States with the yield curve', National Institute Economic Review, May.

Liadze, I. and Hacche, G. (2017), 'The macroeconomic implications of increasing tariffs on US imports', NiGEM Observations, No. 12.

Naisbitt, B. (20|8), 'The re-emergence of concerns about debt', National Institute Economic Review, May.

Riley, R., Rincon-Aznar, A. and Samek, L. (2018), 'Below the aggregate: a sectoral account of the UK productivity puzzle', ESCoE Discussion Paper 2018-06, May. 